\title{
PERANCANGAN SISTEM PENDUKUNG KEPUTUSAN PENENTUAN KARYAWAN TERBAIK PADA CV.YULINDO MULTIPRATAMA JAKARTA
}

\author{
Mochamad Rizki Adityo ${ }^{1}$, Nunu Kustian ${ }^{2}$, Ek Ajeng Rahmi Pinahayu ${ }^{3}$ \\ ${ }^{1,2,3}$ Program Studi Teknik Informatika, Fakultas Teknik dan Ilmu Komputer, \\ Universitas Indraprasta PGRI \\ Jalan Raya Tengah No 80, Kelurahan Gedong, Pasar Rebo, Jakarta Timur \\ muhamad_rizky61@yahoo.com ${ }^{1}$, shinichiunuy@gmail.com², \\ ekajeng_rahmipinahayu@yahoo.com ${ }^{3}$
}

\begin{abstract}
Abstrak
CV.Yulindo Multipratama merupakan perusahaan baru dan masih berkembang yang bergerak dibidang tekstil. Dalam proses persaingan bisnis, diperlukan sumber daya manusia yang kompeten dan selalu termotivasi, salah satu solusinya yaitu dengan membuat sistem yang terkomputersisasi guna meningkatkan motivasi karyawan, yaitu sistem pendukung keputusan penentuan karyawan terbaik. Proses penentuan karyawan terbaik CV. Yulindo Multipratama masih dilakukan secara konvensional sehingga kurang objektif dan efektif. Untuk mengatasi masalah tersebut, diperlukan suatu sistem yang baik. Metode yang penulis gunakan dalam membuat sistem pendukung keputusan yaitu metode Analytical Hierarchy Process, serta untuk pengumpulan data dengan cara oberservasi, wawancara, studi pustaka, dan kuisioner. Hasil dari penelitian ini adalah adanya aplikasi sistem pendukung keputusan penentuan karyawan terbaik dengan metode AHP. Dengan adanya program Sistem Pendukung Keputusan Penentuan Karyawan Terbaik Pada CV. Yulindo Multipratama, secara tidak langsung dapat memotivasi karyawan, menjadikan pemilihan karyawan terbaik menjadi lebih objektif dan dilakukan secara terkomputerisasi.
\end{abstract}

Kata kunci : Analytical Hierarchy Process, CV.Yulindo Multi Pratama, karyawan, Sistem Pendukung Keputusan

\begin{abstract}
CV.Yulindo Multipratama is a new and still developing company engaged in textiles. In the process of business competition, competent and always motivated human resources are needed. One solution is to create a computerized system to increase employee motivation, namely a decision support system for determining the best employees. The process of determining the best employee of $\mathrm{CV}$. Yulindo Multipratama is still done conventionally so it is less objective and effective. To solve this problem, we need a good system. The method that I use in making a decision support system is the Analytical Hierarchy Process method, as well as for data collection by means of observation, interviews, literature study, and questionnaires. The result of this research is the application of a decision support system for determining the best employee using the AHP method. With the program of Determination of the Best Employee Decision Support System at CV. Yulindo Multipratama, can indirectly motivate employees, making the selection of the best employees more objective and computerized.
\end{abstract}

Keyword : Analytical Hierarchy Process, CV. Yulindo Multi Pratama, employees, decision support system

\section{PENDAHULUAN}

Sumber daya manusia merupakan salah satu aset terpenting perusahaan demi mempertahankan, mengembangkan dan meningkatkan daya saing dengan perusahaan lain demi mendapatkan laba serta keuntungan. Ketatnya persaingan di dunia industri 4.0 memicu para pelaku dunia bisnis untuk berupaya lebih keras dalam meningkatkan kualitas dan daya saing perusahaan. Salah satu caranya dengan meningkatkan sumber daya manusia untuk meningkatkan produktifitas dan prestasi perusahaan. Demi menjaga dan meningkatkan kualitas para karyawan, maka perusahaan perlu melakukan upaya seperti salah satunya yaitu pemilihan karyawan terbaik. Berdasarkan data yang diperoleh hingga saat ini, pemilihan karyawan terbaik yang berjalan di CV.Yulindo Multipratama saat ini masih belum dilakukan.

Untuk menyelesaikan masalah tersebut, diperlukan suatu sistem pendukung keputusan karyawan terbaik yang baik. Menurut Turban, Efraim, Sharda, Ramesh \& Delen (2011:90), Sistem 
Pendukung Keputusan dapat didefinisikan sebagai sebuah sistem yang dimaksudkan untuk mendukung para pengambil keputusan menejerial dalam situasi keputusan tidak terstruktur. Sistem Pendukung Keputusan dimaksudkan untuk menjadi alat bantu bagi para pengambil keputusan untuk memperluas kapabilitas mereka, namun tidak untuk mengganti penilaian mereka [1]. Salah satu metode yang digunakan dalam membuat sistem tersebut adalah metode Analytical Hierarchy Process (AHP). Analytical Hierarchy Process merupakan metode yang digunakan untuk penentuan karyawan terbaik. Sedangkan menurut Supriyono (2010: 60), Analytical Hierarchy Process (AHP) merupakan suatu model pendukung keputusan yang dikembangkan oleh Thomas L. Saaty [2]. Sementara menurut Kazibudzki \& Tadeusz (2013), Analytic Hierarchy Process (AHP) adalah pengambilan keputusan multi kriteria dengan dukungan metodologi yang telah diakui dan diterima sebagai prioritas yang secara teori dapat memberikan jawaban yang berbeda dalam masalah pengambilan keputusan serta memberikan peringkat pada alternatif solusinya. Alasan menggunakan metode AHP adalah karena terdapat eigenvector yang digunakan untuk melakukan proses perangkaian prioritas setiap kriteria berdasarkan matriks perbandingan berpasangan [3]. Alasan memilih metode AHP dikarenakan AHP memiliki beberapa keunggulan di antaranya yaitu membandingkan kriteria secara berpasangan sehingga didapat suatu bobot nilai dari tiap-tiap kriteria, serta dengan menggunakan AHP permasalahan yang ada didekomposisi berdasarkan kriteria yang lebih spesifik menggunakan hierarki sistem sehingga menemukan alternatif solusi yang optimal.Dari penjelasan di atas, maka penulis mengambil judul penelitian yaitu "Sistem Pendukung Keputusan Karyawan Terbaik CV.Yulindo Multi Pratama”

Rumusan masalah dalam penelitian ini adalah apa karyawan dapat lebih termotivasi dengan adanya Sistem Pendukung Keputusan Penentuan Krayawan Terbaik di CV.Yulindo Multipratama. Tujuan Penelitian ini adalah memberi solusi akan Sistem Pendukung Keputusan Penentuan Karyawan Terbaik yang lebih objektif, serta membangun sebuah Sistem Pendukung Keputusan Penentuan Karyawan Terbaik yang dilakukan secara terkomputerisasi pada CV.Yulindo Multipratama. Manfaat Penelitian ini berupa adanya sistem yang objektif dalam penilaian penentuan karyawan tebaik dan data laporan yang nyata dalam penentuan karyawan terbaik

\section{PENELITIAN RELEVAN}

Penelitian dari I Dewa Ayu Eka Yuliani (2011) yang berjudul Sistem Pendukung Keputusan Pemilihan Karyawan Terbaik Dengan Metode Analytical Hierarchy Process. Vol.3 No.2 tahun 2011. Program Studi Teknik informatika, jurnal Sistem Informasi dan Teknologi Informatika STMIK Pontianak. Hasil penelitian ini adalah Sistem Pendukung Keputusan Pemilihan Karyawan Terbaik dengan Metode Analytical Hierarchy Process. Penilaian kinerja karyawan di pada KFC Gajah Mada Pontianak dipengaruhi oleh beberapa kriteria yaitu cleanliness (kebersihan), hospitality (keramahtamahan), accuracy (ketepatan), maintenance (perawatan peralatan), product quality (kualitas produk), speed (kecepatan). Perhitungan dari metode AHP memberikan hasil yaitu urutan tingkat kepentingan kriteria dan rekomendasi karyawan terbaik, dimana urutan kriteria yang paling penting dimulai dari product quality, cleanliness, accuracy, maintanace, speed, dan hospitality. Persamaan dengan penelitian ini yaitu menggunakan metode Analytical Hierachy Process (AHP) dalam penentuan karyawan terbaik. Sedangkan perbedaan dengan penelitian tersebut yaitu penelitian tersebut menggunakan 6 kriteria dalam penentuan karyawan terbaik, sedangkan penulis menggunakan 4 kriteria dalam penentuan karyawan terbaik [4].

Penelitian Rima Melati Munthe dan Anita Sindar RMS (2018) yang berjudul Sistem Pendukung Keputusan Menentukan Karyawan Terbaik Dengan Metode AHP. Vol.3 No.2 September tahun 2018. Program Studi Sistem Informasi, jurnal Informatika Sunan Kalijaga. Hasil penelitian ini adalah pemberian julukan karyawan terbaik untuk memacu karyawan yang lain berlomba-lomba memberikan yang terbaik terutama pelayanan kepada pelanggan. Metode Analytical Hearachy Process (AHP), memerlukan kriteria-kriteria dalam mengambil sebuah keputusan sehingga bisa terpilih karyawan terbaik dengan lebih cepat dan objektif. Ada 4 kriteria: Attitude, Absensi, Kinerja dan Masa Kerja. Persamaan dengan penelitian ini yaitu menggunakan metode Analytical Hierachy Process (AHP) dalam penentuan karyawan terbaik, serta menggunakan 4 kriteria dalam penentuan karyawan terbaik. Sedangkan perbedaan dengan penelitian tersebut yaitu 
kriteria-kriteria pemilihan dalam penentuan karyawan terbaik yang berbeda. Kriteria yang penulis pilih yaitu prestasi kerja, tanggung jawab, kerja tim dan disiplin [5].

\section{METODE PENELITIAN}

\section{Observasi}

Menurut Nimatuzzahroh (2018:155), observasi merupakan salah satu metode asesmen psikologi yang utama, selain daripada wawancara. Sebagai sebuah metode asesmen, observasi menjadi sebuah kegiatan yang bertujuan, terancang dan terlaksana dengan sitematis, sekaligus harus terukur. Observasi bukanlah sebuah kegiatan sekedar mengamati [6]. Penulis melakukan observasi CV. Yulindo Multipratama pada Desember 2019 hingga Maret 2020.

\section{Wawancara}

Menurut Slamet \& Rosi (2011:136), wawancara yaitu cara yang dilakukan untuk mendapat informasi melalui kegiatan interaksi sosial antara peneliti dengan yang diteiti [7]. Penulis melakukan wawancara dengan cara mengirim pesan, panggilan telepon dan bertanya secara langsung dalam kurun waktu Desember 2019 hingga Maret 2020.

\section{Studi Pustaka}

Menurut Sugiarti \& Andalas (2020:33), studi pustaka adalah studi yang digunakan dengan menggunakan dokumen sebagai naskah utamanya seperti naskah, buku, koran, majalah, dan lainnya [8]. Penulis melakukan studi pustaka pada Desember 2019 hingga Maret 2020.

\section{Kuisioner}

Menurut Sumarwan (2018:65), Kuisioner adalah instrumen untuk mengambil data dari responden, serta pengukur konsep dan variabel dalam desain survey [9]. Kuisioner diberikan kepada responden terpilih sebagai sampel penelitian. Penulis memilih M. Taufik selaku HRD CV. Yulindo Multipratama sebagai responden karena HRD adalah pihak yang paling mengetahui keadaan karyawan pada suatu perusahaan sehingga cocok untuk menjadi responden pada penelitian ini

\section{Langkah-langkah Pengembangan Sistem}

Model pengembangan sistem yang dilakukan dalam membangun aplikasi administrasi pembayaran sekolah yaitu menggunakan model air terjun (waterfall). Menurut Sukamto, R. A., \& Shalahuddin, (2013: 29), "Model air terjun menyediakan pendekatan alur hidup perangkat lunak secara sekuensial atau terurut dimulai dari analisis, desain pengodean, pengujian dan tahap pendukung (support)" [10]. Langkah-langkah pengembangan sistem yang dibutuhkan untuk merancang sebuah sistem secara rinci, yaitu sebagai berikut:

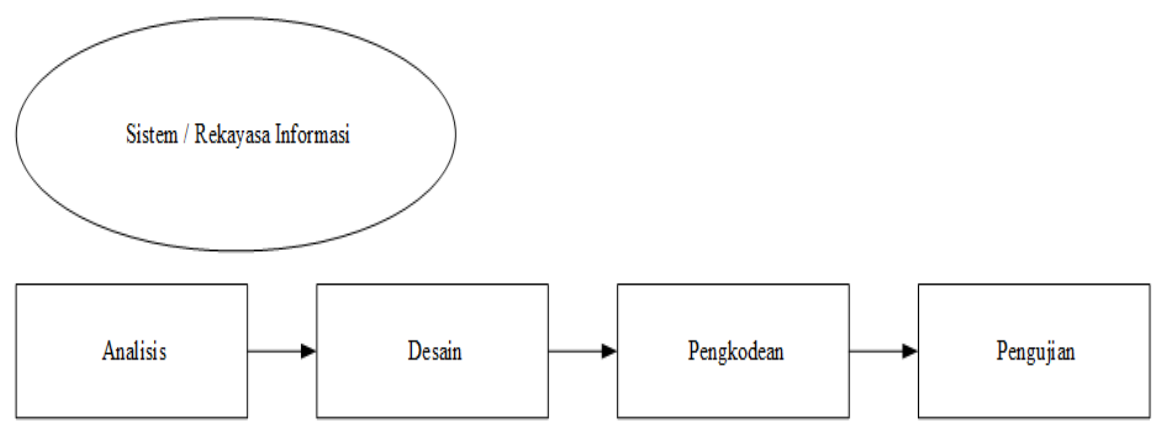

Gambar 1. Model Waterfall

(Sumber: (Sukamto, R. A., \& Shalahuddin, 2013:29)

\section{Analisis Kebutuhan Perangkat Lunak}

Dalam tahap ini, penulis melakukan proses pengumpulan kebutuhan secara intensif agar dapat dipahami untuk mengatur kebutuhan perangkat lunak seperti apa yang dibutuhkan oleh admin CV. Yulindo Multipratama.

\section{Desain}

Dalam tahap ini, penulis menentukan kriteria-kriteria yang dibutuhkan dalam perhitungan dengan metode AHP untuk menentukan desain Sistem Pendukung Keputusan Penentuan Karyawan 
Terbaik pada CV. Yulindo Multipratama agar dapat membuat perangkat lunak yang mudah user friendly dan mudah dipahami oleh admin.

\section{Pembuatan Kode Program}

Pada tahap ini, penulis membuat kode program. Yang disesuaikan dengan desain yang sudah ditranslasikan ke dalam program perangkat lunak. Hasil pada tahap ini adalah program komputer sesuai dengan desain yang sudah dibuat pada tahap desain.

\section{Pengujian}

Pada tahap pengujian, penulis membuat dan melakukan pengujian terhadap aplikasi dengan menggunakan black box testing. Dengan tujuan untuk memastikan setiap bagian sudah sesuai dengan alur proses yang ditetapkan dan memastikan semua kesalahan masukan yang dilakukan oleh pengguna dapat ditangani oleh admin CV. Yulindo Multipratama.

\section{HASIL DAN PEMBAHASAN}

\section{Analisa Permasalahan}

CV. Yulindo Multi Pratama merupakan sebuah UKM yang berkembang, dimana struktur organisasi dan oprasional perusahaan masih tergolong kecil. Belum ditentukan metode yang tepat dalam penentuan karyawan terbaik. Selain itu belum ditentukan standar kriteria penentuan karyawan terbaik yang tepat sehingga kurang objektif. Serta tidak ada data yang nyata mengenai hasil laporan penilaian kinerja karyawan. Hal ini mendorong peneliti untuk mencoba mengembangkan Sistem Pendukung Keputusan Penentuan Karyawan Terbaik pada CV.Yulindo Multipratama.

\section{Diagram Konteks Sistem yang Diusulkan}

Berikut adalah Diagram Konteks pada Sistem Pendukung Keputusan Penentuan Karyawan Terbaik Pada CV. Yulindo Multipratama:

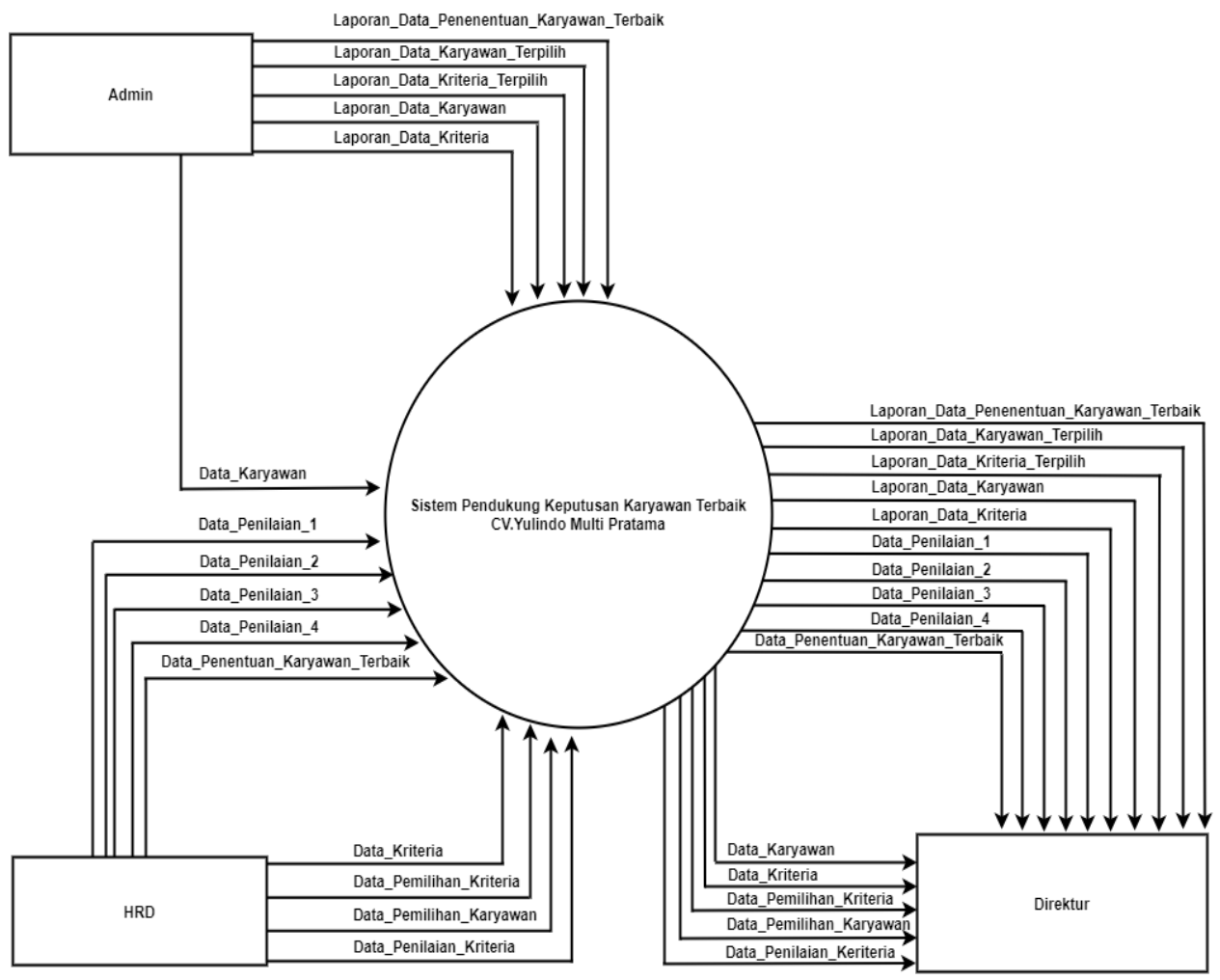

Gambar 2. Diagram Konteks Sistem yang Diusulkan 


\section{Entity Relation Diagram (ERD)}

Berikut adalah Entity Relation Diagram (ERD) pada Sistem Pendukung Keputusan Penentuan Karyawan Terbaik Pada CV. Yulindo Multipratama:

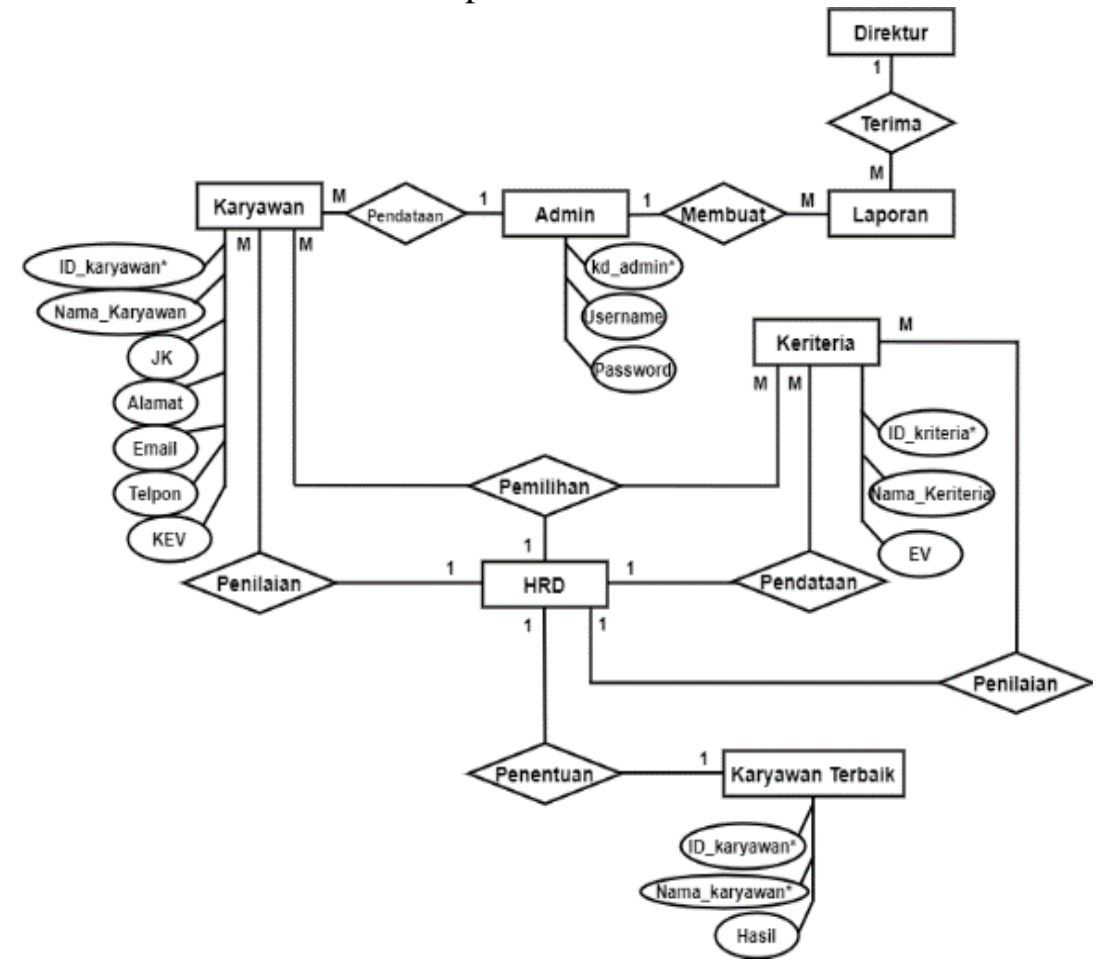

Gambar 3. Entity Relation Diagram (ERD)

\section{Tampilan}

Berikut ini adalah tampilan hasil Perancangan Sistem Pendukung Keputusan Penentuan Karyawan Terbaik pada CV.Yulindo Multipratama:

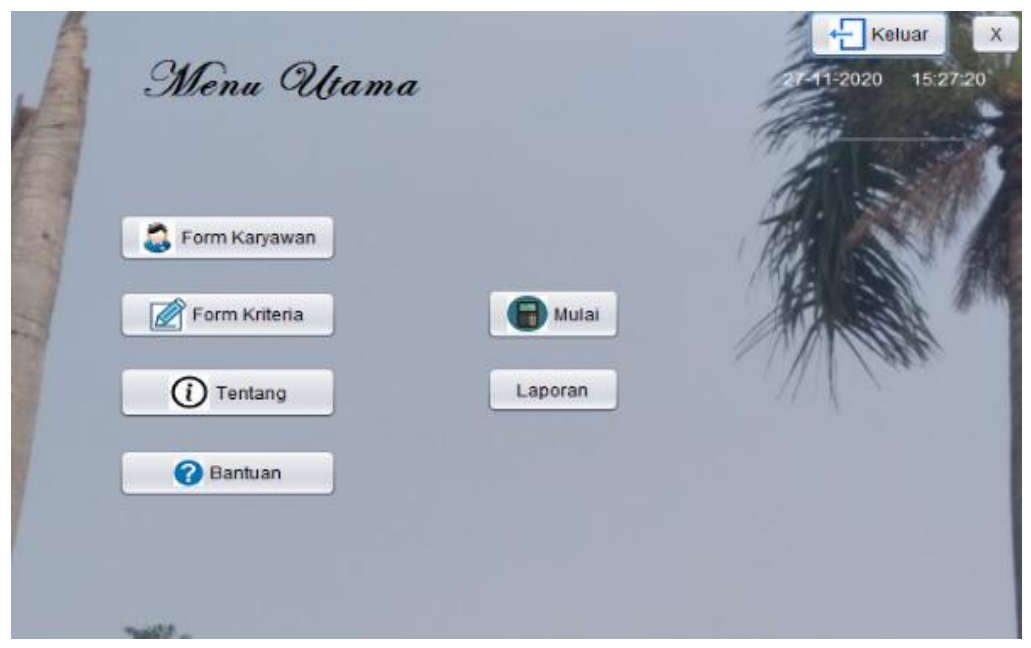

Gambar 4. Tampilan Menu Utama

Layar di atas adalah tampilan form menu utama yang berisikan menu form karyawan, form kriteria, tentang, bantuan, mulai, serta laporan. 


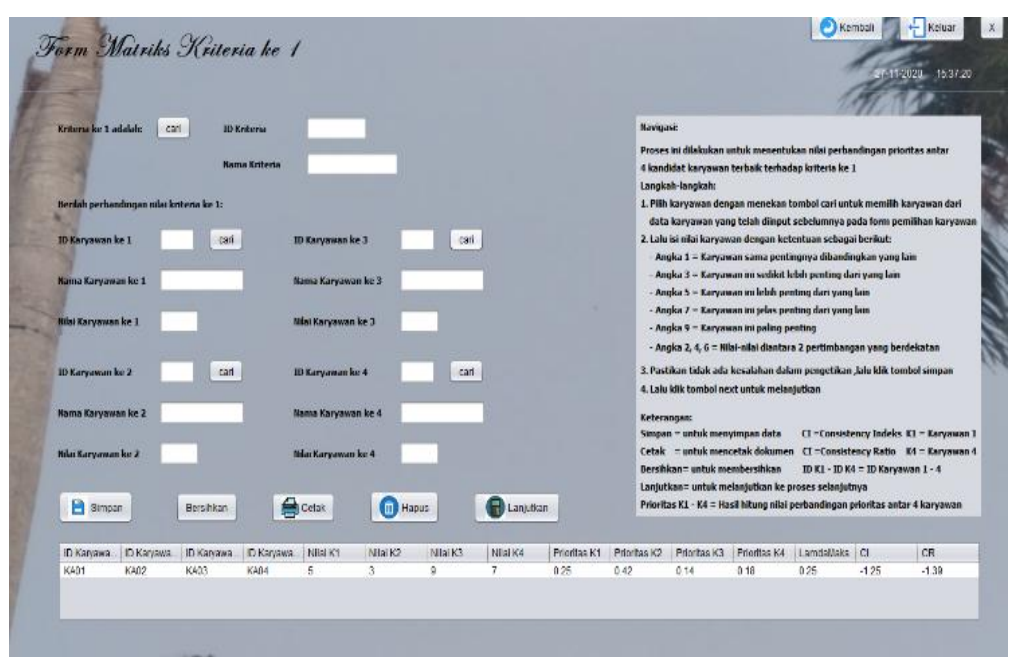

Gambar 5. Tampilan Data Penilaian Karyawan

Layar di atas adalah tampilan form input data penilaian karyawan yang berisi id karyawan 1 sampai id karyawan 4, nama karyawan 1 sampai nama karyawan 4, serta nilai karyawan 1 sampai nilai karyawan 4 .

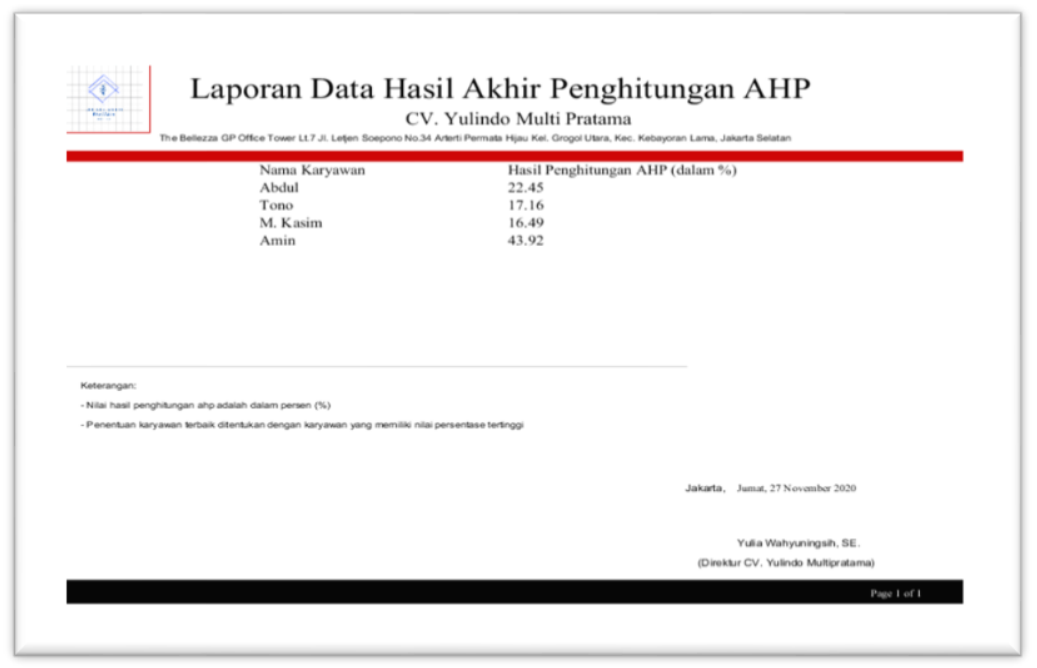

Gambar 6. Tampilan Laporan Data Penilaian Hasil Penghitungan AHP

Layar di atas adalah tampilan laporan data hasil akhir penghitungan AHP yang berisi nama karyawan, dan hasil penghitungan ahp (dalam \%).

\section{Hasil Pengujian Black Box}

Berikut Adalah hasil pengujuan blackbox Sistem Pendukung Keputusan Penentuan Karyawan Terbaik CV. Yulindo Multipratama pada form penentuan karyawan terbaik: 
Tabel 1. Hasil Pengujian Black Box

\begin{tabular}{|c|c|c|}
\hline Aksi Aktor & Reaksi Sistem & $\begin{array}{c}\text { Hasil } \\
\text { Pengujian }\end{array}$ \\
\hline Alur Dasar & & \\
\hline 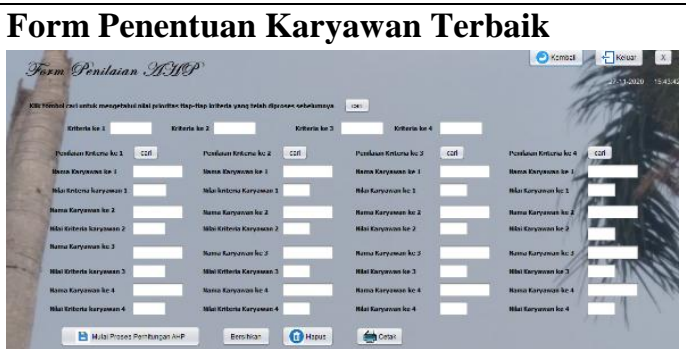 & $\begin{array}{l}\text { Dalam form penentuan } \\
\text { karyawan terbaik sudah } \\
\text { ckup baik, karena semua } \\
\text { tombol sudah dicoba dan } \\
\text { dapat berfungsi sesuai } \\
\text { fungsinya serta tidak } \\
\text { ditemukan adanya error. }\end{array}$ & $\begin{array}{l}\text { Cukup } \\
\text { baik }\end{array}$ \\
\hline
\end{tabular}

\section{Langkah Penghitungan AHP}

Adapun langkah dalam perhitungan AHP sebagai berikut:

1. Menentukan kriteria, yaitu prestasi kerja, kerja tim, loyalitas, dan disiplin.

2. Membentuk matrik pairwise comparison kriteria. Pertama melakukan perbandingan nilai prioritas dari masing-masing kriteria (perbandingan ditentukan dengan mengamati kebijakan yang dianut oleh penilai):

a. Kriteria prestasi kerja bernilai 3, artinya lebih penting dari kerja tim dan loyalitas, namun tidak lebih penting dari disiplin.

b. Kriteria kerja tim bernilai 2, artinya lebih penting dari loyalitas, namun tidak lebih penting dari disiplin dan prestasi kerja.

c. Kriteria loyalitas bernilai 1 , maka menjadi kriteria paling rendah prioritasnya.

d. Kriteria disiplin bernilai 4, maka mendapat nilai paling tinggi.

Dari hasil perbandingan diatas, dapat dibentuk matriks perbandingan (pairwise comparison). Berikut adalah matriks perbandingan kriteria:

\begin{tabular}{|c|c|c|c|c|}
\hline & $\begin{array}{c}\text { Prestasi } \\
\text { Kerja }\end{array}$ & $\begin{array}{c}\text { Kerja } \\
\text { Tim }\end{array}$ & Loyalitas & Disiplin \\
\hline $\begin{array}{c}\text { Prestasi } \\
\text { Kerja }\end{array}$ & 1 & $3 / 2$ & 3 & $3 / 4$ \\
\hline $\begin{array}{c}\text { Kerja } \\
\text { Tim }\end{array}$ & $2 / 3$ & 1 & 2 & $2 / 4$ \\
\hline Loyalitas & $1 / 3$ & $1 / 2$ & 1 & $1 / 4$ \\
\hline Disiplin & $4 / 3$ & 2 & 4 & 1 \\
\hline
\end{tabular}

3. Langah penghitungan selanjutnya yaitu menghitung eigen vactor normalisasi dengan cara menjumlahkan tiap baris kemudian dibagi dengan jumlah kriteria. Dalam kasus ini jumlah keriterianya adalah 4 .

\begin{tabular}{|c|c|}
\hline Kriteria & Eigen Vector \\
\hline Prestasi Kerja & 0,3 \\
\hline Kerja Tim & 0,2 \\
\hline Loyalitas & 0,1 \\
\hline Disiplin & 0,4 \\
\hline
\end{tabular}


4. Langkah selanjutnya yaitu menghitung rasio konsistensi untuk mengetahui apakah penilaian perbandingan keriteria bersifat konsisten.

a. Memeriksa konsistensi untuk tiap kriteria:

1) Prestasi Kerja : $(0.3 \times 1)+(0,3 \times 0.67)+(0.3 \times 0.33)+(0.3 \times 1.33)=1.2$

2) Kerja Tim: $(0.2 \times 1.5)+(0,2 \times 1)+(0.2 \times 0.5)+(0.2 \times 2)=0.8$

3) Loyalitas : $(0.1 \times 3)+(0,1 \times 2)+(0.1 \times 1)+(0.1 \times 4)=0.4$

4) Disiplin: $(0.4 \times 0.75)+(0,4 \times 0.5)+(0.4 \times 0.25)+(0.4 \times 1)=1.6$

b. Menentukan nilai Eigen Maksimum ( $\lambda$ maks). Bagi setiap kolom demean vector prioritas

1) Prestasi Kerja : $1.2 \times 0.3=4$

2) Kerja Tim: $0.8 \times 0.2=4$

3) Loyalitas : $0.4 \times 0.1=4$

4) Disiplin: $1.6 \times 0.4=4$

5) Maka Jumlah $=(4+4+4+4)=16$

6) $\lambda$ maks $=16 / 4=4$

c. Menghitung Indeks Konsistensi (CI)

$\mathrm{CI}=(\lambda$ maks $-\mathrm{n}) /(\mathrm{n}-1)$

$\mathrm{CI}=(4-4) /(4-1)$

$\mathrm{CI}=0$

d. Rasio Konsistensi $=\mathrm{CI} / \mathrm{RI}$, nilai RI untuk $\mathrm{n}=4$ adalah 0,90. Maka:

$\mathrm{CR}=\mathrm{CI} / \mathrm{RI}=0 / 0,90=0$

Karna CR $<0,100$ berarti preferensi pembobotan adalah konsisten.

5. Menentukan nilai perbandingan antara 4 karyawan pada 4 kriteria yang terpilih, ulangi langkah 2 dan 3 sebanyak 4 kali, yaitu pertama menentukan perbandingan nilai karyawan kriteria ke 1, yaitu dengan mengulangi langkah 2 dan 3. Kedua menentukan perbandingan nilai karyawan kriteria ke 2, yaitu dengan mengulangi langkah 2 dan 3. Ketiga menentukan perbandingan nilai karyawan kriteria ke 3, yaitu dengan mengulangi langkah 2 dan 3. Keempat menentukan perbandingan nilai karyawan kriteria ke 4, yaitu dengan mengulangi langkah 2 dan 3.

6. Langkah terakhir yaitu menentukan global priority yang akan menentukan prioritas penentuan karyawan terbaik. Berikut adalah table hasil akhir dari perhitungan global priority.

\begin{tabular}{|c|c|c|c|c|c|}
\hline & $\begin{array}{c}\text { Prestasi } \\
\text { Kerja }(0.3)\end{array}$ & $\begin{array}{c}\text { Kerja Tim } \\
(0.2)\end{array}$ & $\begin{array}{c}\text { Loyalitas } \\
(0.1)\end{array}$ & $\begin{array}{c}\text { Disiplin } \\
(0.4)\end{array}$ & $\begin{array}{c}\text { Gobal } \\
\text { Priority }\end{array}$ \\
\hline Karyawan1 & 0.018 & 0.018 & 0.057 & 0.132 & 0.22 \\
\hline Karyawan2 & 0.030 & 0.054 & 0.044 & 0.044 & 0.18 \\
\hline Karyawan3 & 0.010 & 0.008 & 0.132 & 0.015 & 0.16 \\
\hline Karyawan4 & 0.013 & 0.011 & 0.937 & 0.019 & 0.43 \\
\hline
\end{tabular}

7. Hasil akhir yang menentukan prioritas utama yang menentukkan karyawan terbaik adalah karyawan dengan nilai global priority terbesar. Prioritas diurutkan dari yang terbesar hingga yang terkecil. Maka Karyawan 4 menjadi prioritas utama dengan nilai 0.43 atau $43 \%$, diikuti Karyawan 1 dengan nilai 0.22 atau 22\%, Karyawan 2 dengan nilai 0.18 atau $18 \%$, lalu prioritas terakhir adalah Karyawan3 dengan nilai 0.16 atau $16 \%$.

\section{SIMPULAN}

Berdasarkan analisis penulis, Program ini dapat memberi solusi akan Sistem Pendukung Keputusan Penentuan Karyawan Terbaik yang lebih objektif pada CV.Yulindo Multipratama sehingga dapat memicu semangat kerja para karyawan, serta bermanfaat dalam mengambil keputusan dengan metode yang lebih objektif, efisien dan efektif. Dari hasil penghitungan diperoleh urutan prioritas pertama yaitu Karyawan 4 yang terpilih sebagai karyawan terbaik dengan nilai 0.43 atau $43 \%$. Diikuti oleh Karyawan 1 dengan nilai 0.22 atau 22\%, lalu Karyawan 2 dengan nilai 0.18 atau 18\%, lalu prioritas terakhir adalah Karyawan 3 dengan nilai 0.16 atau $16 \%$. 


\section{DAFTAR PUSTAKA}

[1] Turban, Efraim, Sharda, Ramesh \& Delen, D. (2011). Decision Support and Business Intellegence Systems (9th ed.). Asia: Pearson Education Inc.

[2] Supriyono. (2010). Sistem Pendukung Keputusan Untuk Pemilihan Perguruan Tinggi Komputer Swasta. Jurnal Dasi Issn: 1411-3201, Vol.2, hlm:3.

[3] Kazibudzki, \& Tadeusz, P. (2013). On Some Discoveries In The Field Of Scientific Methods For Management Within The Concept Of Analytic Hierarchy Process. Interational Journal Of Business and Management, Vol. 8, hlm:5-6.

[4] Yuliani, I. D. A. (2011). Sistem Pendukung Keputusan Pemilihan Karyawan Terbaik Dengan Metode Analytical Hierarchy Process. Jurnal Sistem Informasi Dan Teknologi Informatika Pontianak, Vol.3 No.2, hlm:105-114.

[5] Munthe, Rima Melati, \& RMS, Anita Sindar. (2018). Sistem Pendukung Keputusan Menentukan Karyawan Terbaik Dengan Metode AHP, JISKa, Vol.3, No.2 September, 2018, hlm:119-125.

[6] Nimatuzzahroh. (2018). Observasi: Teori Dan Aplikasi Dalam Psikologi. Malang:UMMPress.

[7] Slamet, \& Rosi, F. (2011). Teori Wawancara Psikologi. Yogyakarta:LeutikaPrio.

[8] Sugiarti, \& Andalas, E. F. (2020). Desain Penelitian Kualitaatif Sastra. Malang:UMMPress.

[9] Sumarwan, U. (2018). Riset Pemasaran dan Konsumen Seri 1. Bogor:IPB PRESS.

[10] Sukamto, R. A., \& Shalahuddin, M. (2013). Rekayasa perangkat lunak terstruktur dan berorientasi objek. Bandung:Informatika Bandung. 